\title{
MARKETING MANAGEMENT OF A BRAND
}

\author{
BEATA NOWOTARSKA-ROMANIAK, ${ }^{1}$ \\ ANASTAZJA MAGDALENA KASZTALSKA ${ }^{2}$ \\ University of Economics in Katowice, Faculty of Management, POLAND \\ ${ }_{1}^{1}$ e-mail: beata.nowotarska-romaniak@ue.katowice.pl \\ 2 e-mail: anastazja.kasztalska@gmail.com
}

RECEIVED
ACCEPTED
JEL
CLASSIFICATION

KEYWORDS

ABSTRACT
6 November 2018

3 December 2018

$\mathrm{A} 10, \mathrm{M} 10, \mathrm{M} 40, \mathrm{M} 41$

management, marketing, brand, brand management

Branding refers to many aspects of a company's functioning, as it means a product, a product line, or an entire assortment of companies, as well as a graphic representation of the symbol used by the company. The last meaning of the term "brand" is the whole image of the company that uses it. Nowadays, the brand is a commodity in itself, because consumers often choose to buy something because it is branded with a particular company. Contemporary big international brands have acquired personality, are present in culture, art and everyday life. Branded items are much more desirable than the goods offered by niche brands that are not known. Clients expect not only a product that will meet their needs, but will also carry a certain added value, for example, by brand image, a customer who owns a company items, will be seen as prosperous, professional and trustworthy. The main goal of the article is to show the brand tools used in the marketing, which creates the demand of a product. The second goal is to present are levels inside brand, diversity of a brand and brand identity in the context of a marketing.

\section{Bpand as a tool used in a marketing}

Brand is one of the basic and the most necessary tools used in marketing. A good brand wins and maintains markets and is a good indicator of goodwill. Familiar branded products develop international trade, co-operation and commodity exchange. 
The term "brand" has at least three meanings. It can mean an assortment, a product, an entire line of products similar to one another, a family of products that are close to one another, or an entire assortment that a company has. Another meaning of the term "brand" is the graphical representation of the symbol, which makes the company use it is recognizable on the market, otherwise known as a trademark. The last meaning is a "thinking shortcut" that functions as an image of a product, a set of products, or the whole company that offers them (Bennet, 1995, p. 18).

In marketing, the approach combining these three definitions is very important: the brand is a product in itself that offers functional and added value that is valued by some consumers so much that they choose to buy a branded business product which value is added. They are the highest. Customers buy goods and services to meet their desires and needs. They do not only pay for the material thing, but also for the different values that a given product can offer. The product to succeed in the market must have a high ability to meet the needs of buyers. The benefits of the brand offers to its identity in the marketplace and the brand identity of the potential buyer. The brand should be individual and distinguishable in the way of other, similar, functioning in a given market sector (Jones, Slater, 1986, p. 29).

Throughout the centuries brands were very important and they were significant in the history of trade and industry. Many different companies tried to improve their brand mark to be more and more recognizable. Trademarks evolved from very complicated symbols, that very often included the names of the founders and the date of creation of the company to very simple and minimalistic signs which are very easy to remember by customers (Briciu, Briciu, 2016, p. 137).

Contemporary big, recognizable and transnational brands are the personalities that are present in our culture and everyday life, like sports heroes, movie stars and fictional characters. The way managers shape the brand image requires the use of multiple strategies, different tools and functional strategies (Arnold, 1992, p. 2).

\section{Featurpes of a apand used in a mapketing strategy of a company}

The basic and most important feature of the brand is to offer a product that is distinct and different from the products offered by other organizations. This distinction is an integral part of the product, just like design, packaging or complementary services. This is, however, a component that directly relates to the product's psychological differentiation. Products offered by companies has to be completely different by its individual features than the others.

From a particular industry, they often function in a similar way, the brand is something that makes a product unique and individual on the background of others. Mark, has an identification function, which allows to:

- indicate the country or region where the product was manufactured,

- indicate the producer or distributor,

- easily identify individual product characteristics,

- pay attention to the functional and emotional values of the product or service,

- inform and encourage a specific type of customer who is looking for and values the specific features and characteristics of the product,

- create an image of the buyer and the user of the product both in their own consciousness and in the awareness of others,

- provide a specific type of technical culture (Kotler, 1994, p. 410-411). 
The task of the brand is also to perform an information function, which consists in direct or indirect transmission. Direct communication, this is a simple message in the reception regarding the characteristics of the product, its use, purpose or properties contained in the logo or brand name. Intermediate media is designed to create specific associations and ideas about the brand.

The information function is closely linked to the promotional function, which informs the buyer of the features and functions offered by the brand. The promotional function, which is created by the manufacturer and later by the seller, seen from the consumer, becomes an information function. In order for the brand to enter the desired promotional role, it must first be the promotion itself. A brand that is not recognizable by potential customers is not a brand they deserve and want.

On the part of the consumer needs, a warranty function is a very important function, meaning that the manufacturer is committed to maintaining the quality of the product offered for a specified period of time. With the logo the consumer can easily identify the manufacturer and his level of responsibility for his product. Companies that offer non-branded products are anonymous in the mind of the buyers, and thus the prices of the products they offer are not comparable to those of the well known and reputable brands (Altkorn, 1999, p. 14).

Nowadays a lot of international brands need to improve to meet clients needs, which are quite different between countries and cultures. Modern and flexible brands are aware of these differences and are fully capable to generate a brand identity which is matched for each country. The different branding between countries allows companies to individualize their brand and strengths to the country (Maran, Stockhammer, 2012).

\section{Marketing levels inside brand}

Brand elements are considered on several levels and inform the level of branded product. Graphical representation of all levels resembles circles on water that radiate from the smallest to the largest. The first one is the generic level, it consists of the basic benefit flowing from the product. This level does not differentiate the brand because it expresses the elementary use and the destination of the item, it is called the "kernel" of the product. The next level is the expected level that defines the minimum requirements of the target customer that is the potential recipient of the product. These requirements create expectations for price, performance, dimensions, packaging and availability. Expected level is very important when the customer has no experience in a particular market segment and is guided by the superficial characteristics of the product. The next level from the inside is an extended level, where non-material values appear, which can be crucial to customers with knowledge of the product.

At this level it may happen that several brands are equally satisfying the consumer's expectations, then the customer focuses his attention on the characteristics of the products that distinguish themselves from, for example, symbolic and emotional factors. Very important elements at this stage are: before and during the purchase, warranty covering the product and services related to the goods. The last level is the potential level, which increasingly becomes a requirement for the brand, as it is increasingly expected and evaluated by customers. It includes: brand reputation, brand image, brand name, perceived value, perceived quality, and even the atmosphere of the store. This is a collection of factors that increase the benefits of the buyers and thus develop their brand loyalty (de Chernatony, McDonald, 1994, p. 5).

Marketing communication is significant in branding. Without it the company is not able to fully communicate with the customer whom needs they are trying to fulfill. Without knowledge how to speak and listen to the customer 
the brand would lose its main goal which is to be recognized so being able to generate income. Communication is also an extremely important tool used in marketing and advertising (Belch, Belch, 2012).

\section{Marketing diversity of a brand}

The task of brand managers is to create such features and attributes at all of the aforementioned levels, so that the assortment of a given company stands out against other products in the same segment. Differentiation of the brand consists in transforming neutral and non-differentiated goods into specific one sand individual, who in the consumer's mind will offer a bunch of benefits not available to the competition. The management must carefully decide which ones are the most important.

This may lead to an increase in profits from the sale of the product but also to the additional costs associated with the production of the differentiated product range. The decision on diversification is based on perceptual and economic criteria. Perceptual criteria, are related to the receipt of the product by the customer and to create in its consciousness specific features of the product. In order for the diversification strategy to succeed, several criteria must be met:

a) an average consumer with limited knowledge and knowledge of the product's technical data must be aware of the innovation and individuality of the product he/she has chosen; differentiating features must be visible and not only known to manufacturers and constructors;

b) the advantages of the differentiated product must be desirable by the customer; often this requires a promotional action, because in the case of innovative goods, i.e. novelty on the market, the buyer is not aware of the benefits, and thus will not seek it or desire it;

c) a clear distinction between the products of the enterprise and competition; in the case of brands with a long history, new elements should be added and the well-known features;

d) the product can not declare non-existent features, as this affects the negative image of the business and results in a lack of customer loyalty;

e) the client must be informed about the differences and benefits of diversification through all available forms of communication, then only the business can benefit.

Economic criteria relate to profitability, i.e. the profitability of product differentiation. To make changes to their products, the company should consider such factors as:

- include a real number of buyers who will be interested in the new features of the product enough to buy it, and thus bring the production and sales team to the appropriate and profitable size of the business,

- the ability to be interested in a varied product of new buyers and develop loyalty to the brand and product to customers who know the company and the range offered by it,

- difficult to copy new features used in the product by the competition. It is important that competition cannot easily introduce the same changes and innovations in its products (Murphy, 1987, pp. 78-80).

An identity that is influenced by image (image) that functions in the consciousness of the audience and the identity of the brand created by the management and the owner is a very important element of each brand. Identity aims to define the meaning, design and branding, and thus outperforms the brand's image. Image of a company (characteristics of it) is a combination of all the features through which consumers visualize their brand name, logo, assortment, advertising or sponsorship (Shmitt, Simonson, 1999, p. 65). 
Nowadays a lot of customers prefer to copy their idols. This is very visible in the United Kingdom where the Royal Family creates trends regarding luxury and luxury branding. Brits prefer to buy what the dynasty choose because they find them as elegant and definitely worth imitation (Otnes, Maclaran, 2015, pp. 167-169).

\section{Marketing brand identity}

A brand that already has a longer time in the market gains meaning and autonomy, it makes its individual character by choosing it at the stage of creation from all possible options. Identity consists of the entire past of the company, including past promotional activities and products. Symbols and branding mean that the brand is used in marketing strategy. Identity creates consistency and the realism of the brand, defines the limits of its positioning, regulates the means of expression, creates its individuality and ensures durability, by regulating what is the brand, what it does and how it does. In the process of creating a brand, the management and the owner must make sure that it is primarily concrete, that is, easily defined. Another important attribute of the brand is its ability to meet customer needs and thus exploit all the weaknesses of competing brands. Brand identity must also be easy to accept and understand by company employees (Kall, 2001, pp. 25-27).

The products of the brand are a source of identity and uniqueness. Managers should strive to ensure that the product bearing the graphic sign of the company does not represent only things but a whole set of material and non-material characteristics associated with it. Values represented by the brand must embody the brand's flagship and most recognizable product. Many companies do not have key products, so their image is shaken and not fixed in the consumer's mind.

Very often the brand name reflects the company's intentions and often introduces innovative naming in the industry sector. Over time, a well-known and recognizable brand changes the meaning of the word in the consumer's mind, which originally meant something else (for example Apple or Mercedes). This is an example that reflects the brand's intentions based on its name, on the basis of which its identity is being built. Another source of identity creation is the choice of graphic elements such as logo. By choosing the right symbols, the company not only represents the product, but also makes the logo represent its personality, culture, and identity, and makes employees identify with the company they work for. Some brands consciously choose their representatives, who are the source for brand identity building. The Coco Chanel or Gianni Versace, for example, or imagined characters, such as mascots or animals, are often brand-specific. Regardless of the choice of "brand face", it aims to create a strong emotional link between the brand and the customer. The use of the character is a well-thought-out marketing technique that helps the buyer to recognize and memorize the features and benefits of a brand that is personalized through a specific character. Very often after a long time running the "ambassador of the brand" it becomes a mythical and legendary figure, even if in the past it really existed. Another way to create a brand identity is to refer to company heritage or country of origin. This action draws consumers' attention to the long history of the brand or its geographical roots. The most important source of brand identity is its advertising, which informs the recipient.

The advantages of the product and the style of the company that offers it. The advertisement is the business card of the company, as it shows the image of the sender, receiver and the relationship between them (Kapferer, 1995, pp. 47-54). 


\section{Methodology}

The survey is focused on selected by interviewer persons that represent interesting and tested qualities. The survey omits persons that do not have features which are being studied. An example is the study of the phenomenon of luxury goods, while respondents are the only owners of the exclusive items, are the observers of the luxury market or are the supporters of it. Every respondent had own, individual opinion about luxury goods. Individuals who for various reasons are not interested in luxury industry, were excluded from the study because they do not have the relevant experience and a clear opinion about the exclusive goods and luxury market (Lynn, 2014, p. 500).

The survey was sent by email to people who are actively participating in the life of luxury industry, as well as fans of it. In a survey 134 people participated. The survey was conducted in January 2018 and in February 2018. Respondents had a very high degree of freedom of expression, because they could modify the questions and add their own observations and comments. Subjects were men and women, diverse in age, as the youngest tested person was 18 years old and the oldest 76 . Age and gender had little significance as a major determinant. The main factor was the wealth of a person who can afford to be an owner of luxury goods.

Respondents were in the higher percentile of wage earners within Poland with wages above 20,000zl per month. The majority of the wealthiest were people above 40 whom had increased their wages throughout their working lives, however there were also some young respondents whom attained their wealth via inheritances.

\section{Results}

Respondents mostly associate the luxury product with the product made with the best materials and with the highest precision (34\%). Another group of people identified an exclusive product with a well-known brand (28\%). Much less popular was the response, indicating that the luxury product was a very expensive and hardly accessible product (8\%). A small group of people pointed out that luxury goods are addressed to a narrow clientele (18\%) and it is an attest to the high social status of its holder (12\%).

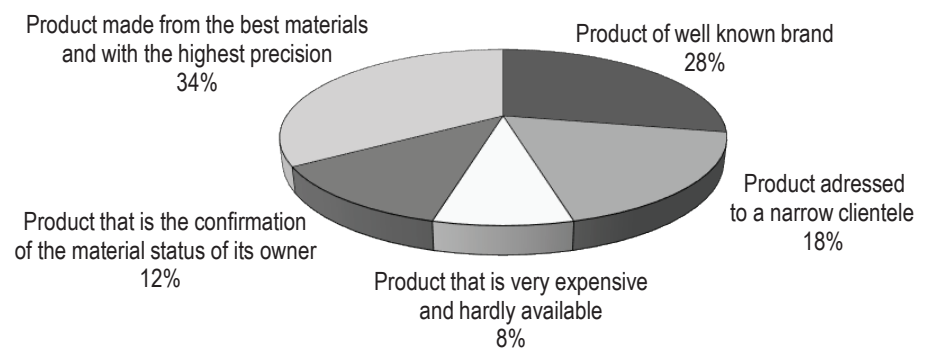

Figure 1. Explanation of what luxury goods are for its clients

Source: own adaptation based upon data from the survey.

Nearly half of the respondents said that when they buy the luxury product the main determinant is the brand $(41 \%)$, with half the group saying that the purchase decision was decided by the opinion about the product $(21 \%)$. 
Another factor that facilitated the decision to purchase was own experience of the buyer (14\%) and advertising influence $(9 \%)$. The most notable factor was the quality of a product $(7 \%)$, packaging $(5 \%)$ and least significant price $(3 \%)$.

In the world the concepts of quality and elegance are critical to the definition of luxury and remain relatively stable from year to year, across all consumers of all nations. These features are particularly important for French consumers $-89 \%$ cite quality, while $79 \%$ of them cite elegance as essential to the meaning of luxury.

The importance of exclusivity is declining: it was mentioned by only $52 \%$ of consumers, compared to $67 \%$ in 2014. Meanwhile, the number of consumers who said craftsmanship was critical to luxury rose by $12 \%$ between last year and this one (Salgues, 2015).

\section{Conclusions}

Marketing activities have a positive influence on building brand prestige. Through marketing activities, the demand for a product is created, and moreover, through marketing activities, the brand can be built, developed and freely designed to suit the needs of the market and customers.

The recognition of a particular brand influences the decision to purchase it. There is a relationship between the brand's degree of recognition and its revenue, which means that the more brand is known, the higher the profit it generates. Customers prefer brands that are known and appreciated by niche brands and not known.

Marketing of a brands increases their visibility and increases the demand for them, for example through advertising campaigns linked to well-known people in politics, sports, arts and culture. Marketing must promote and build brand prestige in the eyes of customers, then it becomes a desirable and willing brand. Demand for branded goods is created by marketing, which creates the need for having products that are the only ones that can satisfy fully the needs of customers.

\section{References}

Altkorn, J. (1999). Strategia marki. Warszawa, PWE.

Arnold, D. (1992). The Handbook of Brand Management. New York: Addison-Wesley Publishing Company.

Belch, G.E., Belch, M.A. (2012). Advertising and Promotion: An integrated marketing communications perspective. New York, NY: McGraw-Hill Irwin.

Bennet, P.D. (1995). Dictionary of Marketing Terms. Chicago: American Marketing Association.

Briciu, V.A, Briciu, A. (2016). A Brief History of Brands and the Evolution of Place Branding. Bulletin of the Transilvania University of Braşov. Series VII: Social Sciences, 9 (58), 137-142.

de Chernatony, L., McDonald, M.H.B. (1994). Creating Powerful Brands. Oxford: Butterworth-Heinemann.

Jones, J.P., Slater, J.S. (1986). What's In Name? Advertising and the Concept of Brands. Lexington: ME Sharpe Inc.

Kall, J. (2001). Silna marka. Istota i kreowanie. Warszawa: PWE.

Kapferer, J.N. (1995). Strategic Brand Management-New Approaches to Creating and Evaluating Brand Equality. Londyn: Kogan Page. Kotler, Ph. (1994). Marketing. Analiza, planowanie, wdrażanie, kontrola. Warszawa: Gebethner i Spółka.

Lynn, P. (2014). Longer interviews may not affect subsequent survey participation propensity. Public Opinion Quarterly, 78 (2), 500-509.

Maran, J., Stockhammer, P.W. (eds.) (2012). Materiality and Social Practice: Transformative Capacities of Intercultural Encounters. Oxford, UK, Oxbow.

Murphy, J.M. (1987). Branding: A Key Marketing Tool. New York: McGraw-Hill.

Otnes, C.C., Maclaran. P. (2015). Royal Fever: The British Monarchy in Consumer Culture. University of California Press. 
Salgues, F. (2015). Understanding the behaviour of luxury consumers. A customer experience group company. Beijing.

Shmitt, B., Simonson, A. (1999). Estetyka w marketingu. Strategiczne zarządzanie markami, tożsamością i wizerunkiem firmy. Kraków: Wydawnictwo Profesjonalnej Szkoły Biznesu.

Cite this anticle aS: Nowotarska-Romaniak, B., Kasztalska, A.M. (2018). Marketing management of a Brand. European Journal of Service Management, 4 (28/1), 223-230. DOI: 10.18276/ejsm.2018.28/1-28. 